\title{
THE INFLUENCE OF NUTRITION DURING OESTRUS ON OVULATION RATE IN THE SOW
}

\author{
G. A. LODGE AND B. HARDY \\ University of Nottingham School of Agriculture, Sutton Bonington, Loughborough \\ (Received 5th October 1967)
}

\begin{abstract}
Summary. In an initial experiment with forty gilts, doubling the daily feed allowance from 1.8 to $3.6 \mathrm{~kg}$ for only the first feed following service in early oestrus increased significantly the subsequent litter size from $8.95 \pm 0.53$ to $10 \cdot 8 \pm 0.40$ pigs born. In a second experiment with twenty gilts, the increase in feed allowance was from 1.4 to $4.1 \mathrm{~kg}$ for the single feed given $12 \mathrm{hr}$ after onset of oestrus and this increased significantly the number of corpora lutea at the 13th day of pregnancy from $12 \cdot 14 \pm 0 \cdot 86$ to $14 \cdot 71 \pm 0 \cdot 42$.
\end{abstract}

Although it has long been known that the level of feeding of pigs before ovulation influences the number of ova shed, the minimum period over which this effect is operative does not appear to have been established. Following earlier work in which different feed levels were given over periods of 3 weeks or more (Robertson, Casida, Grummer \& Chapman, 1951; Christian \& Nofziger, 1952; Self, Grummer \& Casida, 1955), it was found that ovulation could be stimulated by increasing energy intake for as little as 14, 10 or even 6 days before oestrus by reducing the fibre level of the diet (Zimmerman, Self \& Casida, 1957), by adding glucose (Zimmerman, Spies, Self \& Casida, 1958) or by adding fat (Zimmerman, Spies, Self \& Casida, 1960; Rigor, Meyer, First \& Casida, 1963). Conversely, ovulation rate was reduced by starvation for some 10 days before oestrus (McGillivray, Nalbandov, Jensen, Norton \& Becker, 1962).

In a previous experiment to assess the influence of level of feeding during early pregnancy on embryo survival (Heap, Lodge \& Lamming, 1967), there was an indication that the number of corpora lutea present at the 28th day of pregnancy was influenced by feed consumption following service, which implied that ovulation rate might be influenced by feed intake during the short interval between early oestrus and ovulation some 24 to $36 \mathrm{hr}$ later. Data presented by previous workers suggested a similar occurrence (King \& Young, 1957; Ray \& McCarty, 1965) so the present experiments were initiated to investigate further whether ovulation rate could be influenced by such short term variations in the diet.

The previous experiment (Heap et al., 1967) was with sows, but as variation in ovulation rate is likely to be greater in the sow than the gilt, because of greater opportunity for variation in pre-ovulation treatment, it was decided to use gilts of as uniform weight and age as possible in the present experiments. These were all first cross Large White $\times$ Landrace. 
In the first experiment forty gilts were restricted to a daily feed allowance of $1.8 \mathrm{~kg}(4 \mathrm{lb}) /$ head, individually fed once per day, from $90 \mathrm{~kg}$ live-weight until mated at first oestrus after each reached $122 \mathrm{~kg}$ live-weight. At mating with a Landrace boar, alternate sows were allocated to one of two treatment groups. One continued to receive the same daily feed allowance of $1.8 \mathrm{~kg}$ (controls); the other received $3.6 \mathrm{~kg}(8 \mathrm{lb})$ for the first feed after service and then returned to $1.8 \mathrm{~kg} /$ day for the remainder of pregnancy (flushed). All were fed once daily at approximately 09.00 hours.

All gilts were served twice with a 24-hr interval, the first service being as early in oestrus as possible so that the additional feed for the flushed group came between the two. Litter size at birth was taken as an indication of ovulation rate, on the assumption that difference in a single feed before ovulation was unlikely to influence embryo survival and not ovulation rate.

Composition of the diet used throughout, given in dry cube form, is shown in Table 1. All animals also had free access to straw on a deep-litter housing system.

TABLE 1

GOMPOSITION OF THE DIET

\begin{tabular}{lc}
\hline & \\
Ground barley & $50 \%$ \\
Ground wheat & $40 \%$ \\
White fishmeal & $5 \%$ \\
Soyabean meal & $5 \%$ \\
Plus $10 \%$ of a mineral/vitamin supplement* & \\
Digestible energy value & $3186 \mathrm{kcal} / \mathrm{kg}$ \\
Crude protein & $15 \cdot 6 \%$ \\
Ca & $0 \cdot 6 \%$ \\
$\mathbf{P}$ & $0.6 \%$ \\
\hline
\end{tabular}

* Supplement provides $/ \mathrm{kg}$ diet: $\mathrm{Ca}, 1.9 \mathrm{~g} ; \mathrm{P}, 1.0 \mathrm{~g} ; \mathrm{NaCl}$, $2.5 \mathrm{~g}$; Fe, $60 \mathrm{mg} ; \mathrm{Mn}, 12 \mathrm{mg}$; $\mathrm{Zn}, 50 \mathrm{mg}$; vitamin A, 6000 i.u.; vitamin $\mathrm{D}_{3}, 250$ i.u.; riboflavine, $2.5 \mathrm{mg}$; nicotinic acid, $10 \mathrm{mg}$; pantothenic acid, $2.5 \mathrm{mg}$; vitamin $\mathrm{B}_{12}, 10 \mu \mathrm{g}$; vitamin $\mathrm{E}$, $10 \mathrm{mg}$.

In Exp. 2, twenty gilts were fed $2.3 \mathrm{~kg}(5 \mathrm{lb}) /$ day of the same diet (Table 1) from puberty until third oestrus, when they were reduced to $1.4 \mathrm{~kg}(3 \mathrm{lb}) /$ day. They remained at this level of intake until mated at fourth oestrus, after which they either continued at the same level or were increased to $4 \cdot 1 \mathrm{~kg}(9 \mathrm{lb})$ for the single feed given $12 \mathrm{hr}$ after observed onset of oestrus. Also in this experiment, to help reduce variation in the time interval between the increase in feed consumption and ovulation, the gilts were tested twice daily with a boar from a week before anticipated oestrus and were inseminated artificially $30 \mathrm{hr}$ after its observed onset. All were slaughtered on the 13th day after insemination for examination of the ovaries.

In Exp. 1, all twenty gilts in each experimental group which were mated farrowed with the following results:

$\begin{array}{cccc} & \text { Controls } & \text { Flushed } & \text { Difference } \\ \text { Mean number born } & 8.95 \pm 0.53 & 10 \cdot 8 \pm 0 \cdot 40 & 1.85 \pm 0.67 \\ t_{(38)}=2 \cdot 76 ; \text { significant at the } 1 \% \text { level. } & \end{array}$


In Exp. 2, of nine gilts served in the control group and twelve in the flushed group, only seven in each had ovulated on slaughter at the 13th day after mating. This unusually high incidence of failure to ovulate might have been related to the low level of feeding $(1.4 \mathrm{~kg} /$ day) of both groups for the 3 weeks before service. The performance of those which did ovulate was as follows:

$\begin{array}{cccc} & \text { Controls } & \text { Flushed } & \text { Difference } \\ \text { Mean number corpora lutea } & 12 \cdot 14 \pm 0 \cdot 86 & 14 \cdot 71 \pm 0.42 & 2 \cdot 57 \pm 0.96 \\ t_{(12)}=2 \cdot 69 ; \text { significant at the } 2 \% \text { level. } & \end{array}$

The results of the two experiments indicate that an increased feed intake a few hours before ovulation resulted in an increased number of ova shed, and that this may be expected to result in a greater number of pigs born, although the full difference in number of ovulations might not be reflected in numbers born because of greater embryo mortality.

It is of interest to consider whether the very high feed allowance before ovulation causes a superovulation effect or merely restores to normal a depression in ovulation resulting from the previous low level of feeding. Thus, in Exp. 1, the control gilts given a daily feed allowance of $1.8 \mathrm{~kg}$ meal for several weeks before mating produced litters with an average number of 8.95 pigs, which is lower than would be expected for such animals. In previous experiments average litter sizes for gilts were 10.4 (Lodge \& MacPherson, 1961), 11.1 (Lodge, Elsley \& MacPherson, 1966) and 10.5 (Lodge, unpublished data), which suggests that in the present experiment the flushed gilts might be regarded as normal while the control gilts were sub-normal.

The results of Exp. 2 tend to support this suggestion that flushing was rectifying a depressing effect of feed restrictions on ovulation rate, in that comparison with previous published values suggests that corpora lutea counts of over fourteen are not exceptional for full-fed gilts (Hammond, 1914; Christian \& Nofziger, 1952; Self et al., 1955; Hafez, 1958; Zimmerman et al., 1960; McGillivray et al., 1962; Rigor et al., 1963; Schulz, Speer, Hays \& Melampy, 1966) and the increase of 2.57 in ovulation rate is comparable to that generally reported for flushing of a longer duration.

The authors are indebted to $\mathrm{Mr}$ A. M. Schofield for his help in making corpora lutea counts, and to Mr C. R. Newman and Mr D. K. White for their care of the animals.

\section{REFERENCES}

Christian, R. E. \& Nofziger, J. C. (1952) Puberty and other reproductive phenomena in gilts as affected by plane of nutrition. (Abstract). F. Anim. Sci. 11, 589.

HAfEz, E. S. E. (1958) Reproduction, placentation and prenatal development in swine as affected by nutritional environment. (Abstract). J. Anim. Sci. 17, 1212.

Hammond, J. (1914) On some factors controlling fertility in domestic animals. J. agric. Sci., Camb. 6, 263.

Heap, F. C., Lodge, G. A. \& Lamming, G. E. (1967) The influence of plane of nutrition in early pregnancy on the survival and development of embryos in the sow. 7. Reprod. Fert. 13, 269.

KING, J. W. B. \& Young, G. B. (1957) Maternal influences on litter size in pigs. 7. agric. Sci., Camb. $48,457$.

Lodge, G. A., Elslex, F. W. H. \& Macpherson, R. M. (1966) The effects of level of feeding of sows during pregnancy. I. Reproductive performance. Anim. Prod. 8, 29. 
Lodge, G. A. \& Macpherson, R. M. (1961) Level of feeding during early life and the subsequent reproductive performance of sows. Anim. Prod. 3, 19.

Magillivray, J. J., Nalbandov, A. V., Jensen, A. H., Norton, H. N. \& Becker, D. E. (1962) Reproductive performance in gilts starved or fed different levels of energy. (Abstract). $\mathcal{J}$. Anim. Sci. 21, 1005.

Ray, D. E. \& McGarty, J. N. (1965) Effect of temporary fasting on reproduction in gilts. F. Anim. Sci. 24, 660 .

Rigor, E. M., Meyer, R. K., First, N. L. \& Casida, L. E. (1963) Endocrine differences associated with follicular development and ovulation rate in swine due to breed and energy intake. $\boldsymbol{J}$. Anim. Sci. 22, 43.

Robertson, G. L., Casida, L. E., Grummer, R. H. \& Ghapman, A. B. (1951) Some feeding and management factors affecting age at puberty and related phenomena in Chester White and Poland China gilts. 7. Anim. Sci. 10,841.

Schulz, J. R., Speer, V. C., Hays, V. W. \& Melampy, R. M. (1966) Influence of feed intake and progestogen on reproductive performance in swine. 7. Anim. Sci. 25, 157.

Self, H. L., Grummer, R. H. \& Casida, L. E. (1955) The effects of various sequences of full and limited feeding on the reproductive phenomena in Chester White and Poland China gilts. 7. Anim. Sci. 14, 573 .

Zimmerman, D. R., Self, H. L. \& Casida, L. E. (1957) The effect of flushing for varying lengths of time on the ovulation rate of Chester White and Chester White-Poland China crossbred gilts. (Abstract). 7. Anim. Sci. 16, 1099.

Zimmerman, D. R., Spies, H. G., Self, H. L. \& Casida, L. E. (1958) The effect of glucose feeding on ovulation rate in Chester White gilts. (Abstract). F. Anim. Sci. 17, 1212.

Zimmerman, D. R., Spies, H. G., Self, H. L. \& Casida, L. E. (1960) Ovulation rate in swine as affected by increased energy intake just prior to ovulation. 7. Anim. Sci. 19, 295. 